\title{
Encapsulation of Flurbiprofen by Chitosan Using a Spray-Drying Method with In Vitro Drug Releasing and Molecular Docking
}

\author{
Püskürtmeli Kurutma Tekniği Kullanarak Flurbiprofenin Kitosan ile \\ Enkapsülasyonu ve In Vitro İlaç Salınımı ve Moleküler Modelleme Çalışmaları
}

\author{
Lalehan AKYÜZ1* ${ }^{*}$ Fatih DUMAN2, Murat KAYA3 \\ 1Aksaray University, Faculty of Technical Vocational, Department of Chemistry Technology, Aksaray, Turkey \\ 2Erciyes University, Faculty of Science, Department of Biology, Kayseri, Turkey \\ ${ }^{3}$ Aksaray University, Faculty of Science and Letters, Department of Biotechnology and Molecular Biology, Aksaray, Turkey
}

\begin{abstract}
Objectives: This study aimed to prepare chitosan-flurbiprofen micro-nano spheres as environmentally friendly for drug releasing by spray-drying method without any cross-linking agent. It was also aimed to reveal the favorable binding geometries of chitosan and flurbiprofen using molecular modeling.

Materials and Methods: In this study, flurbiprofen was encapsulated with chitosan using spray-drying technique. The used chitosan, flurbiprofen and obtained spheres were characterized via fourier transmission infrared spectrometer (FT-IR), thermogravimetric analysis (TGA), X-ray diffractometer and scanning electron microscopy (SEM). Drug entrapment efficiency was carried out for determination of the drug amount in the micro-nano spheres. In vitro release studies of CS-FP spheres were also examined in the simulated biological fluid at $\mathrm{pH}$ 7.4. Encapsulation process of flurbiprofen was combined with the docking studies to investigate the possible binding sites of the chitosan.

Results: FT-IR results confirmed that $\mathrm{H}$-bonding system was formed between chitosan and drug. CS-FP spheres with spherical shape were observed by SEM. TGA analysis results showed that thermal stabilities of flurbiprofen and chitosan were decreased after the encapsulation process. The spheres were used for in vitro releasing studies in simulated biological fluids. All these analysis results clearly showed that encapsulation was successfully carried out with $73.28 \%$ efficiency. Molecular modeling studies showed that CS-FP stable complexes was formed through a hydrogen bonding system between $\mathrm{OH}$ group of the drug molecule and chitosan hydroxyl (OH) group with a binding energy of $-3.90 \mathrm{kcal} / \mathrm{mol}$. Our computational results supported to spectroscopic results obtained by FTIR. Conclusion: This study proved that micro-nano spheres can be prepared without using cross-linking agent by spray-drying method. The results of the drug releasing studies showed that release of encapsulated flurbiprofen was completed within 48h. The results of docking analysis can be suggested for the design of new drug carrier systems with chitosan.
\end{abstract}

Key words: Biodegradable, drug delivery, molecular docking, characterization

ÖZ

Amaç: Bu çalıșma, herhangi bir çapraz-bağlama ajanı kullanmadan püskürterek kurutma tekniği ile ilaç salınımı için, kitosan-flurbiprofen mikro ve nano küreleri hazırlamayı amaçlamaktadır. Ayrıca moleküler modelleme kullanarak kitosan ve flurbiprofen arasındaki bağlanma geometrisini açıklamayı amaçlamaktadır.

Gereç ve Yöntemler: Bu çalışmada, püskürterek kurutma tekniği kullanarak flurbiprofenin kitosan ile enkapsülasyonu yapıldı. Kullanılan kitosan, flurbiprofen ve elde edilen kürecikler fourier dönüșümlü kızıötesi spektroskopisi (FT-IR), termogravimetrik analiz (TGA), X-ray difraktometre ve taramalı elektron mikroskopisi (SEM) ile karakterize edildi. Mikro-nano küreciklerdeki ilaç miktarının belirlenmesi için ilaç tutunma verimi çalıșıldı. In vitro salınım çalıșmaları pH 7.4 te simüle edilmiş biyolojik sıvı içerisinde gerçekleștirildi. Flurbiprofenin enkapsülasyon prosesi, kitosanın muhtemel bağlanma bölgelerini açıklamak için doking çalışmaları ile birleștirildi.

Bulgular: FT-IR sonuçları kitosan ve flurbiprofen arasında H-bağ sisteminin oluştuğunu göstermektedir. Küresel şekilde CS-FP kürecikler SEM ile açıklandı. TGA analizi sonuçları flurbiprofen ve kitosanın termal kararlııklarının enkapsülasyon sonrası azaldığını göstermektedir. Kürecikler simüle edilmiș biyolojik sıvıda in vitro olarak salınım çalışmaları için kullanılmıştır. Tüm bu analizler enkapsülasyonun \%73.28 etki ile başarılı bir şekilde gerçekleștirildiğini göstermektedir. Moleküler modelleme çalıșmaları bağlanma enerjisi $-3.90 \mathrm{kcal} / \mathrm{mol}$ olarak kitosan $\mathrm{OH}$ grubu ile ilacın hidroksil $(\mathrm{OH})$ grubu arasında H-bağ sisteminin olușması ile CS-FP kararlı kompleks yapısının oluştuğunu göstermektedir. Bilgisayar hesaplamaları sonuçları FT-IR dan elde ettiğimiz spektroskopik sonuçları desteklemektedir.

Sonuç: Bu çalışma püskürterek kurutma yöntemi ile çapraz-bağ ajanı kullanmadan mikro ve nano küreciklerin hazırlanabileceğini göstermiştir. İlaç salınım çalışması sonuçları, enkapsüle olmuş flurbiprofenin salınımının 48 saat içinde tamamlandığını göstermiştir. Doking analizi sonuçları kitosan ile yeni ilaç taşıyıcı sistemlerin tasarlanması için önerilebilir.

Anahtar kelimeler: Biyobozunur, ilaç salınımı, moleküler modelleme, karakterizasyon

*Correspondence: E-mail: lale_akyuz@hotmail.com, Phone: +90 3822282517

Received: 09.06.2016, Accepted: 21.07.2016

๑Turk J Pharm Sci, Published by Galenos Publishing House. 


\section{INTRODUCTION}

Although flurbiprofen is one of the non-steroidal antiinflammatory drugs which is used commonly worldwide for reducing pain and treatment of rheumatoid arthritis and osteoarthritis, ${ }^{1}$ it has some side effects on gastrointestinal systems when it is administrated by oral way. ${ }^{2}$ To minimize these side effects, biodegradable polymeric micro- and nano spheres have been developed for drug releasing. ${ }^{3,4}$ Chitosan is a kind of biopolymer which is with its edible, biodegradable, biocompatible and nontoxic nature ${ }^{5}$ and it was used for encapsulation of some compounds such as doxorubicin, ${ }^{6}$ curcumin, ${ }^{7}$ glycyrrhizin, ${ }^{8}$ insulin ${ }^{9}$ and cyclosporin $A .^{10}$ Chitosan has also been used for delivery of some non-steroidal anti-inflammatory drugs like ibuprofen, ${ }^{11}$ naproxen ${ }^{12}$ and ketoprofen. ${ }^{13}$ In a recently study, ${ }^{14}$ genipin cross-linked chitosan microspheres of flurbiprofen was conducted but in that study, the used cross-linked agent (genipin) has an acute toxicity but in the present study it was tried to prepare chitosan-flurbiprofen microspheres for drug releasing without any cross-linked agent.

Several studies of controlled release systems of flurbiprofen have been reported for the preparation of encapsulated drugs using different methods. ${ }^{15-18}$ However, these methods are complex and expensive, the adjustment of the particle size is difficult. Compared with the other techniques, spray-drying method is relatively simple, fast and cheap for preparation of encapsulated drugs. One of the main advantages of the spray drying method is adjustable of spherical particles size from submicron to micron by controlling the process parameters. ${ }^{19}$

There are several types of intermolecular interactions between two molecules, such as hydrogen bonds, van der Waals interactions, hydrophobic interactions and electrostatic interactions. The molecular docking study is an effective method predicted these interactions and preferred orientation when bound of ligand to macromolecular target to create a stable complex. ${ }^{20}$ In this study, the interaction of flurbiprofen with chitosan will be explained by using molecular docking.

In the present work, we reported the preparation of environmentally friendly chitosan-flurbiprofen micro-nano spheres by using spray-drying method without any cross-linked agent. The morphology and bonding characterization of the spheres were carried out by with scanning electron microscope (SEM) and fourier transform infrared spectroscopy (FTIR) analysis, respectively. The stability of spheres was tested using thermo gravimetric analysis and X-ray diffraction (XRD) analysis. In order to determine of delivering ability of carbon spheres CSFP spheres, in vitro drug release mechanism was examined in the simulated biological fluid at $\mathrm{pH}$ 7.4. Encapsulation efficiency was carried out for determination of the drug amount in the spheres. It was also aimed to reveal the favorable binding geometries of chitosan and flurbiprofen using molecular modeling to support of the spectroscopic analysis of spheres.

\section{MATERIALS AND METHOD}

\section{Materials}

Low molecular weight chitosan (PCode: 1001654970) and flurbiprofen (CAS number: 5104-49-4) were purchased from
Sigma Aldrich Co. (USA). Ethanol and acetic acid of analytical grade were obtained from Merck Chemical Co. (Germany).

\section{Preparation of CS-FP micro-nano spheres}

In this study, CS-FP spheres were prepared by modification of the method described by Kim et al. ${ }^{21}$ CS-FP spheres were prepared using a Buchi B-290 mini spray dryer. $1.0 \mathrm{~g}$ of chitosan was added to $25 \mathrm{~mL}$ of acetate buffer ( $\mathrm{pH}$ 5.5-6.0). Flurbiprofen $(0.75 \mathrm{~g}$ ) was added in $25 \mathrm{~g}$ of ethanol/distilled water in proportions of 10:15 w/w. Flurbiprofen was dissolved by stirring at $500 \mathrm{rpm}$ for $10 \mathrm{~min}$ and the final mixture was heated to $70^{\circ} \mathrm{C}$ until a clear solution was obtained. The clear solution was mixtured with chitosan solution using a magnetic stirrer at $500 \mathrm{rpm}$ and $70^{\circ} \mathrm{C}$ for $2 \mathrm{~min}$. Prepared solutions without a cross-linking agent were spray dried using a spray drier at a flow rate of $5 \mathrm{~mL} / \mathrm{min}$. The process conditions such as aspirator setting, pump setting, inlet and outlet temperatures were set at $100 \%, 20 \%, 100^{\circ} \mathrm{C}$ and $70^{\circ} \mathrm{C}$, respectively. When the solution was evaporated, CS-FP spheres were formed. Dried product was collected in a collecting flask.

\section{Entrapment efficiency}

In order to decide the amount of flurbiprofen in drug loaded spheres, drug entrapment efficiency study was carried out by modification of method of Kawadkar and Chauhan. ${ }^{14}$ For this purpose, $10 \mathrm{mg}$ of CS-FP spheres was weighted and ingested 5 $\mathrm{mL}$ of $3 \mathrm{~N}$ hydrochloride. It was stirred using magnetic stirrer at $50^{\circ} \mathrm{C}$ for $1 \mathrm{~h}$ and cooled up to the room temperature. The mixture was taken into the extraction flask and $5 \mathrm{~mL}$ of chloroform was added to mixture for extraction process. It was strongly shaken to complete extraction of flurbiprofen. After the separating of two phases, organic extract was distinguished from the other phase. Chloroform was completely evaporated at $70^{\circ} \mathrm{C}$. The organic extract was dissolved in ethanol and filtered using 125 $\mu \mathrm{m}$ pore size filter membrane. $0.2 \mathrm{~mL}$ of clear solution was diluted to $5 \mathrm{~mL}$. The absorbance of filtered clear solution was measured at $247 \mathrm{~nm}$. Entrapment efficiency was calculated using equation [1] given below ${ }^{22}$ :

$\% E E=\frac{\text { Calculated amount of flurbiprofen }}{\text { Total amount of flurbiprofen }} \times 100$

\section{Characterization of CS-FP micro-nano spheres}

\section{Scanning electron microscopy analysis}

Surface morphologies of the used chitosan, flurbiprofen and spray-dried CS-FP spheres were investigated using a SEM, FEI, Quanta FEG 250. These materials were made electrically conductive by coating with gold as a thin layer using a Gatan Precision Etching Coating System.

\section{Thermo gravimetric analysis}

The EXSTAR S11 TG/DTA 7300 system was used for the thermal characteristics of chitosan, flurbiprofen and CS-FP spheres. In order to obtain TG curves, samples were analyzed at a heating rate of $10^{\circ} \mathrm{C} / \mathrm{min}$ from 25 to $650^{\circ} \mathrm{C}$ under a nitrogen flow.

\section{Fourier transform infrared spectroscopy}

Interactions between the active agent of drug and biopolymer were examined by FTIR spectroscopy (Perkin Elmer mark 
FTIR Spectrophotometer, USA). The spectra were recorded for flurbiprofen, chitosan and CS-FP spheres at the scanning range of $4.000-650 \mathrm{~cm}^{-1}$.

\section{$X$-ray diffraction}

A Bruker AXS D8 Advance Model XRD was used for investigation of the effect of encapsulation on crystallinity of drug. XRD peaks of chitosan, flurbiprofen and CS-FP spheres were obtained at $40 \mathrm{kV}, 30 \mathrm{~mA}$ and the scanning angle range of $5-90^{\circ} \mathrm{C}$ of $2 \theta$.

\section{In vitro drug release studies}

In vitro drug release studies were performed in phosphate buffer saline (PBS) medium at $\mathrm{pH} 7.4$ for a period of 48 h. 10 $\mathrm{mg}$ of CS-FP spheres were reconstituted in $25 \mathrm{~mL}$ of PBS and moved in dialysis bag. The dialysis bag was placed in $300 \mathrm{~mL}$ of the same PBS at $37^{\circ} \mathrm{C}$ and stirred at $100 \mathrm{rpm}$ using magnetic stirrer. In order to determine the amount of FP released from the dialysis bag at different time intervals $(1 \mathrm{~min}, 5 \mathrm{~min}, 10 \mathrm{~min}$, $15 \mathrm{~min}, 20 \mathrm{~min}, 30 \mathrm{~min}, 1 \mathrm{~h}, 2 \mathrm{~h}, 6 \mathrm{~h}, 24 \mathrm{~h}, 48 \mathrm{~h}$ ), $2 \mathrm{~mL}$ of the samples was picked up and then replaced with the $2 \mathrm{~mL}$ of fresh PBS buffer. The concentration of drug released to the medium was determined by measuring the absorbance at 247 $\mathrm{nm}$ using a ultraviolet spectrophotometer. A calibration curve of FP released to the medium was plotted by concentration against the absorbance. Releasing percentage of FP was calculated from the following equation [2]:

Drug release $(\%)=\frac{\text { Released FP }}{\text { Total FP }} \times 100$

\section{Molecular docking studies}

To determine the interactions between chitosan and flurbiprofen, molecular docking analysis were performed using ArgusLab 4.0.1 docking software which is a free molecular modeling package. ${ }^{23}$ The chemical structure of chitosan was obtained from the literature. ${ }^{24}$ The three dimensional structures were constructed for flurbiprofen and chitosan using Spartan 06 V1.2.0 software. ${ }^{25}$ Geometrical optimization of energy minimized structures of the molecules was performed using semiemprical PM3 method in Spartan'06 V1.2.0 software. Whole structures of the lowest energy conformer of chitosan and flurbiprofen were defined as a potential binding site and a ligand, respectively. Argusdock exhaustive search docking engine with grid resolution of $0.40 \AA$ was used for docking runs. Docking precision was set to high precision with a maximum of 150 candidate poses and flexible ligand docking mode was activated for docking runs. A score was used as the scoring function estimated the free binding energy and binding site box size was set to automatically as $15 \times 15 \times 25$.

\section{RESULTS AND DISCUSSION}

\section{Encapsulation efficiency}

The encapsulation efficiency explains that it is the percentage of the amount of the drug that loaded to drug carrier agent. In this study, it was found as $73.28 \%$. Kawadkar and Chauhan ${ }^{14}$ found the encapsulation efficiency of flurbiprofen loaded chitosan microparticles between $63.39 \%$ and $80.97 \%$. Our result was in accordance with the previous study. ${ }^{14}$

\section{Morphology of CS-FP micro-nano spheres}

The surface morphology of encapsulated drugs is one of the most important elements in order to explain the effectiveness of drug delivery systems. Intermolecular interactions between polymer and drug molecule may change the surface morphology. Therefore, SEM analysis was used to investigate the surface morphology and shape of CS-FP spheres. SEM images of the chitosan, pure drug and CS-FP spheres are shown in Figure 1. Surface morphologies of chitosan were revealed in the form of fibrous and porous, while flurbiprofen surface was consisted of flake like appearance. As seen from the Figure 1, surface morphology of CS-FP spheres was spherical in shape with their diameter changed from $700 \mathrm{~nm}$ to $13 \mu \mathrm{m}$. The appearance of the spheres is fairly smooth throughout the surface. These results indicate that the spheres are separated from the chitosan and pure drug and the flurbiprofen successfully encapsulated into chitosan particles.

\section{Thermal stability}

Thermal stability of chitosan, flurbiprofen and CS-FP spheres were determined and the results are presented in Figure 2. For chitosan, two decomposition phases were observed. The first decomposition ( $7.18 \%$ ) between 30 and $100^{\circ} \mathrm{C}$ was due to evaporation of water and the second mass lose (56.32) between 250 and $650^{\circ} \mathrm{C}$ was because of degradation of polysaccharide structure. The maximum degradation temperature for chitosan was recorded as $298.2^{\circ} \mathrm{C}$. For flurbiprofen, very small degradation ( $0.1 \%$ ) was recorded between 30 and $100^{\circ} \mathrm{C}$ and $99.7 \%$ mass loss was recorded between 130 and $260^{\circ} \mathrm{C}$. This small mass loss in the first step was because of evaporation of little amount of water and the huge degradation in the second step was due to degradation of flurbiprofen. After encapsulation, CS-FP spheres were degraded in three stages. In the first stage, $7.4 \%$ mass loss was observed between 30 and $150^{\circ} \mathrm{C}$ (maximum
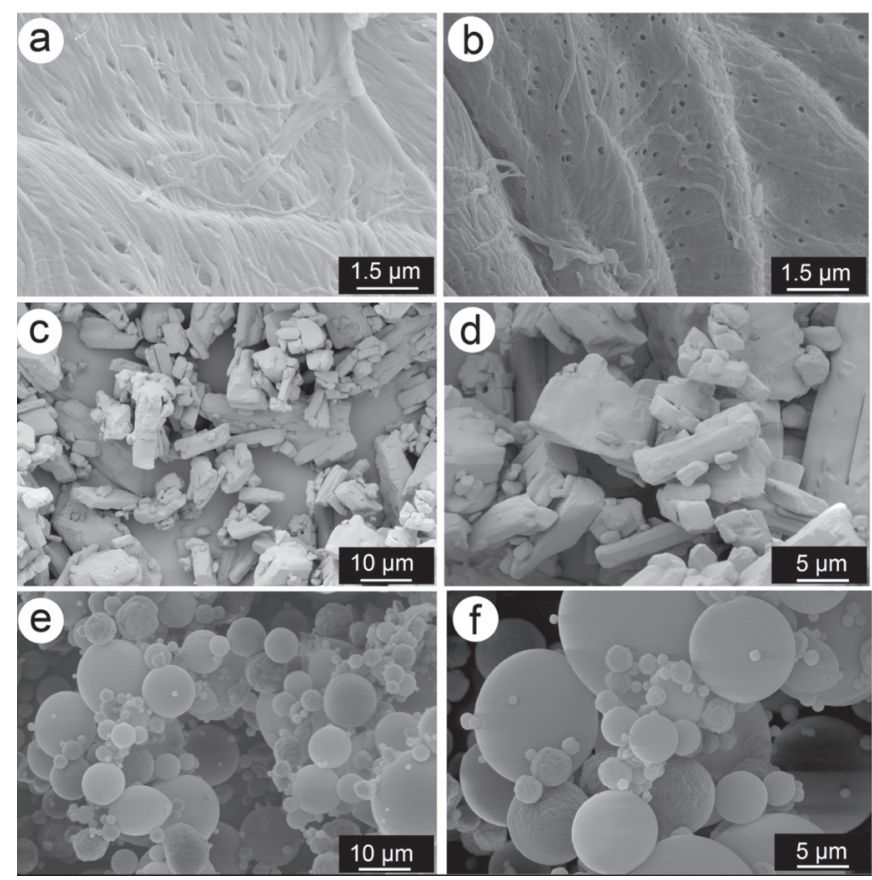

Figure 1. Scanning electron microscope pictures of (a, b) chitosan (c, d) flurbiprofen $(e, f)$ chitosan-flurbiprofen micro-nano spheres 


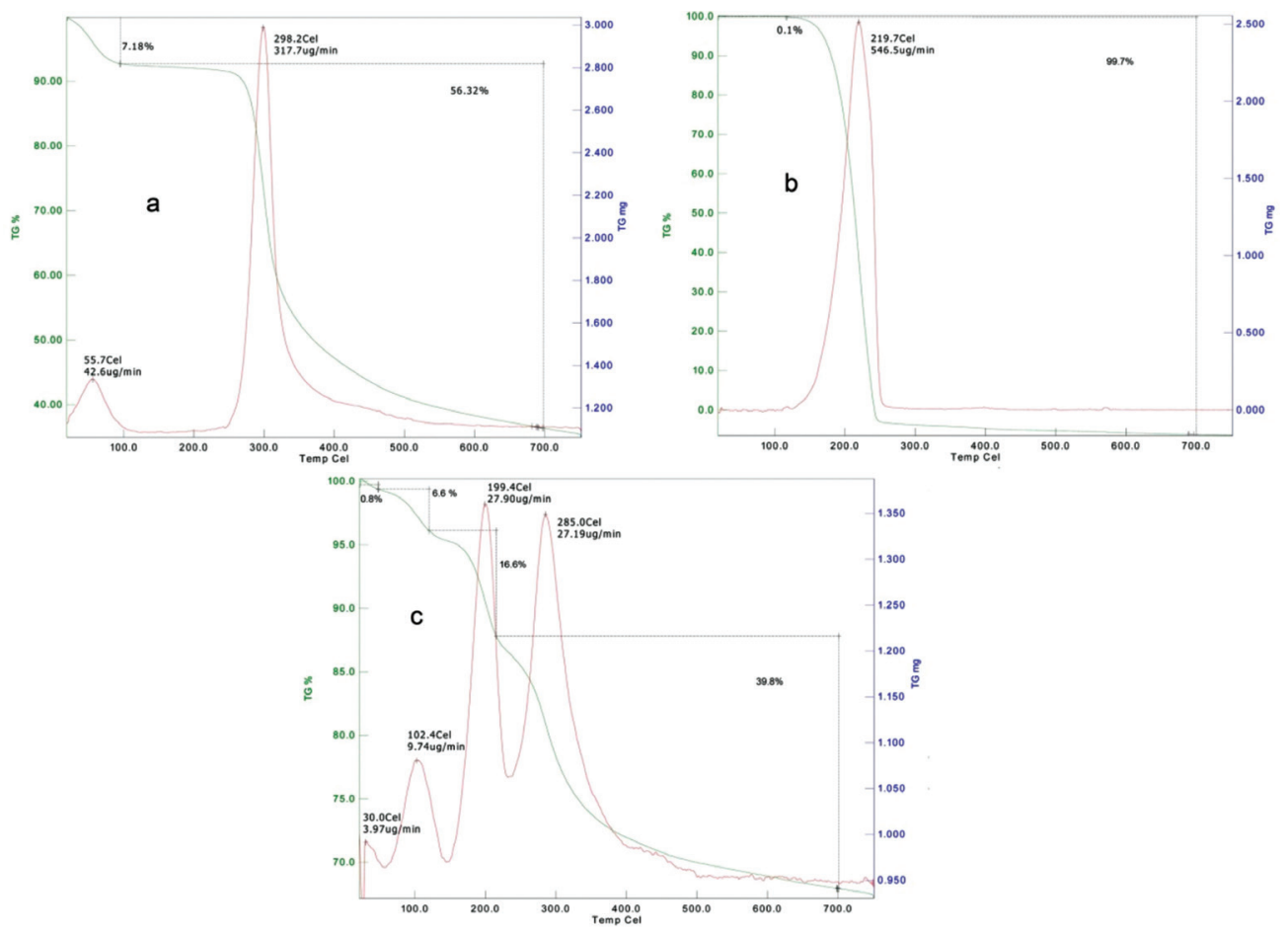

Figure 2. Thermal characteristics of (a) chitosan (b) flurbiprofen and (c) chitosan-flurbiprofen micro-nano spheres

degradation $102.4^{\circ} \mathrm{C}$ ) and it can be attributed to evaporation of water. In the second stage, $16.6 \%$ mass loss was recorded between 150 and $250^{\circ} \mathrm{C}$ (maximum degradation $199.4^{\circ} \mathrm{C}$ ) and it can be attributed to the degradation of flurbiprofen. In the third stage, 39.8\% mass loss was observed between 250 and $650^{\circ} \mathrm{C}$ (maximum degradation $285^{\circ} \mathrm{C}$ ) and it can be ascribed to the degradation of chitosan. After encapsulation, thermal stabilities of flurbiprofen and chitosan were decreased. These characteristic degradations for both chitosan and flurbiprofen in CS-FP spheres showed the successful encapsulation.

\section{$X$-ray diffraction}

XRD patterns of chitosan, pure drug and encapsulated sample are given in Figure 3 . The broad peak observed at $2 \theta=19^{\circ}$ is the characteristic peak for the chitosan. The XRD pattern of flurbiprofen revealed the crystalline structure of drug observed by five sharp peaks at $2 \theta$ of $7^{\circ}, 11^{\circ}, 16^{\circ}, 21^{\circ}$ and $24^{\circ}$. The XRD pattern of flurbiprofen compared with the XRD pattern of encapsulated sample, CS-FP spheres showed no sharp peaks, whereas a broad peak from $11^{\circ}$ to $24^{\circ}$ was observed. Mean of this broad peak is that flurbiprofen was kept in an amorphous state in the chitosan. These results suggest that flurbiprofen successfully encapsulated in the chitosan.

\section{Fourier transform infrared spectroscopy}

FTIR spectroscopy of flurbiprofen, chitosan and CS-FP spheres were instructed to explain drug-biopolymer interaction. FTIR spectrums of flurbiprofen, chitosan and CS-FP spheres were compared in Figure 4. As seen from the Figure 4a, the characteristic sharp peaks of flurbiprofen at 1694.7, 1414.7 and $1216.1 \mathrm{~cm}^{-1}$ were due to $\mathrm{C}=\mathrm{O}$ stretching, $\mathrm{O}-\mathrm{H}$ bending and $\mathrm{C}-\mathrm{F}$ stretching, respectively. The characteristic band of flurbiprofen due to the hydrogen bonds of the carboxyl group appeared in the range of the $3400-2400 \mathrm{~cm}^{-1}$. Characteristic bands of chitosan
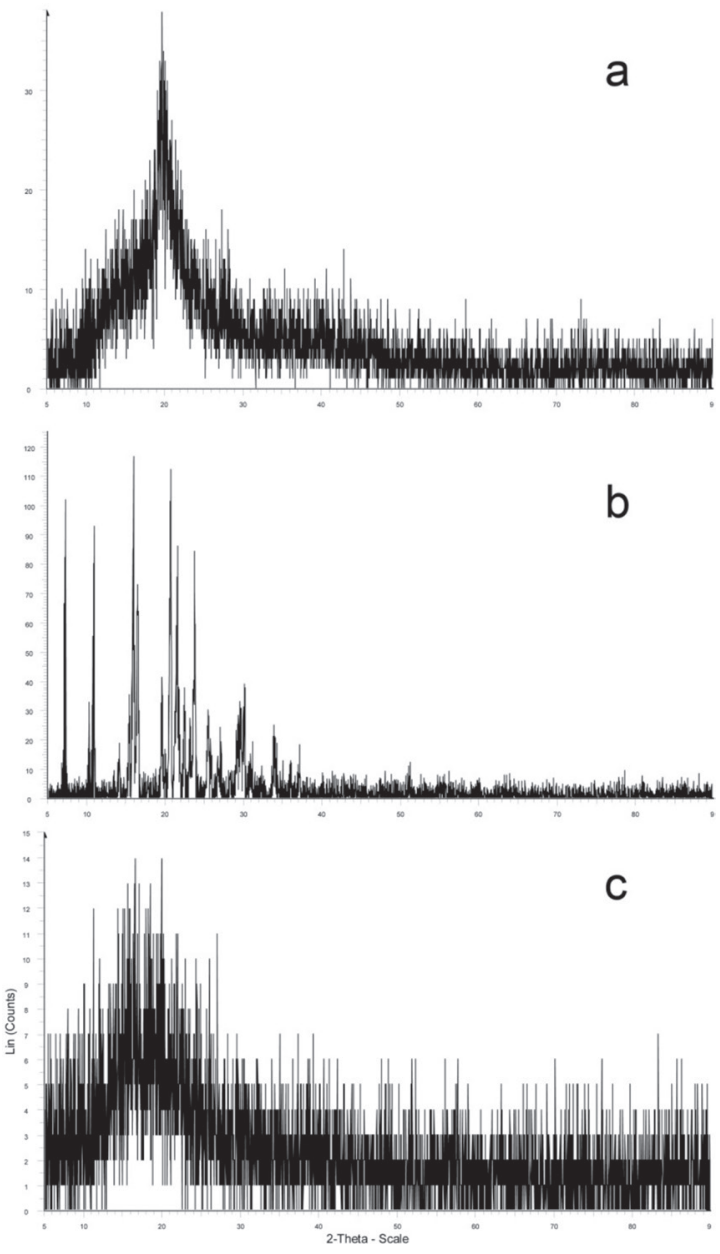

Figure 3. X-ray diffraction pattern of (a) chitosan (b) flurbiprofen and (c) chitosan-flurbiprofen micro-nano spheres 


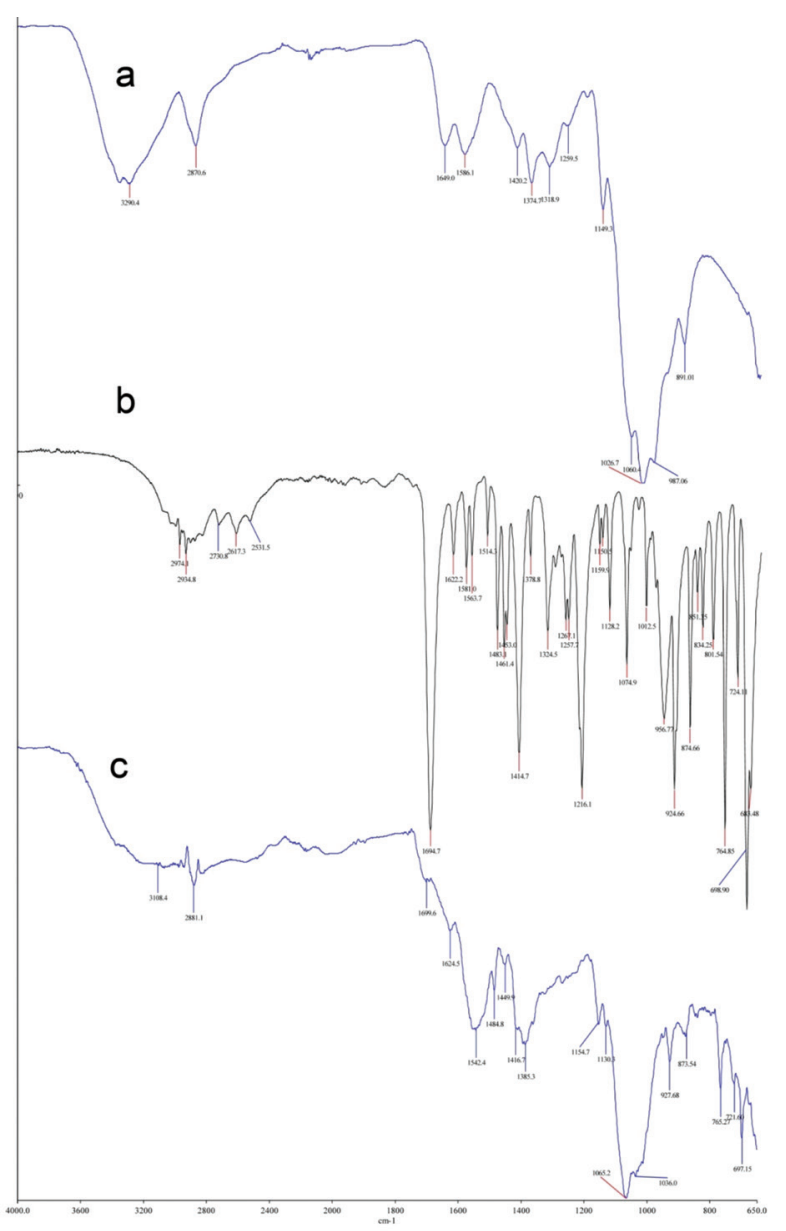

Figure 4. Fourier transform infrared spectroscopy spectrums of (a) chitosan (b) flurbiprofen and (c) chitosan-flurbiprofen micro-nano spheres

were seen from the Figure $4 \mathrm{~b}$ at $3290.4 \mathrm{~cm}^{-1}, 1649.0 \mathrm{~cm}^{-1}, 1586.1$ $\mathrm{cm}^{-1}$ and $1318.9 \mathrm{~cm}^{-1}$ which correspond to $\mathrm{OH}$ and $\mathrm{NH}$ stretching, amide I $(\mathrm{C}=\mathrm{O})$, amide II $\left(\mathrm{NH}_{2}\right)$ and amide III $(\mathrm{C}-\mathrm{N})$, respectively. ${ }^{26}$ Spectrum of CS-FP spheres (Figure 4c) compared with the other spectrums, there are some changes indicating the structural differences of chitosan after the encapsulation process. It is seen that the $\mathrm{O}-\mathrm{H}$ and $\mathrm{N}-\mathrm{H}$ stretching bands were shifted to lower wavenumbers at $3108.4 \mathrm{~cm}^{-1}$ due to $\mathrm{H}$ bonding system. Furthermore, peaks observed at $927.68 \mathrm{~cm}^{-1}$, $765.27 \mathrm{~cm}^{-1}, 721.6 \mathrm{~cm}^{-1}$ and $697.15 \mathrm{~cm}^{-1}$ indicate the presence of the substitute aromatic rings of flurbiprofen. These changes greatly showed that flurbiprofen successfully encapsulated into chitosan particles.

\section{In vitro release}

In order to determine the releasing behavior of drug from the chitosan matrix, drug loaded spheres were examined in PBS to simulate biological environment. The cumulative percentages of CS-FP spheres released at $\mathrm{pH} 7.4$ were presented in Figure 5. As seen from the Figure 5, flurbiprofen released from spheres was completed within 48h. Release profile of CS-FP spheres was found to be biphasic, with an initial fast releasing for $4 \mathrm{~h}$ followed by a slower releasing rate. While cumulative percentage of flurbiprofen released from chitosan is about $54.9 \%$ for the first $4 \mathrm{~h}$, it is $99.37 \%$ for $48 \mathrm{~h}$. The main

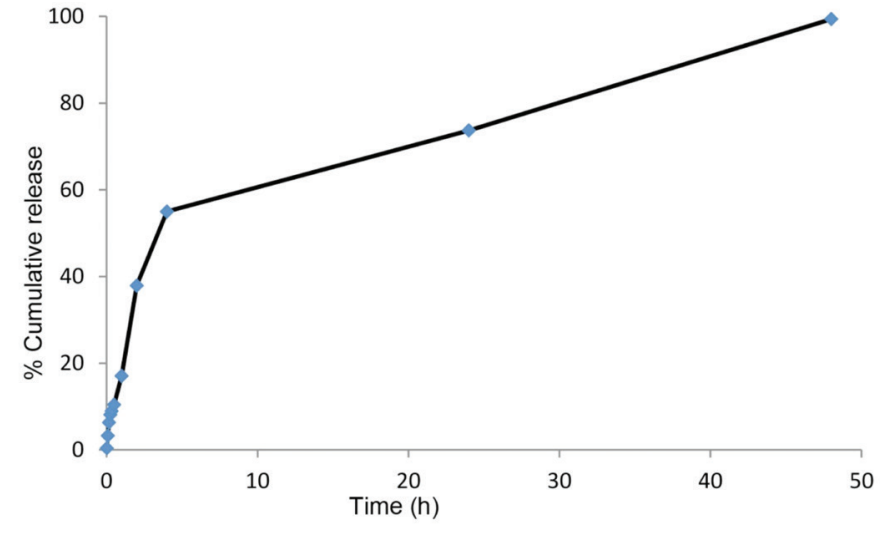

Figure 5. Releasing profile of chitosan-flurbiprofen micro-nano spheres

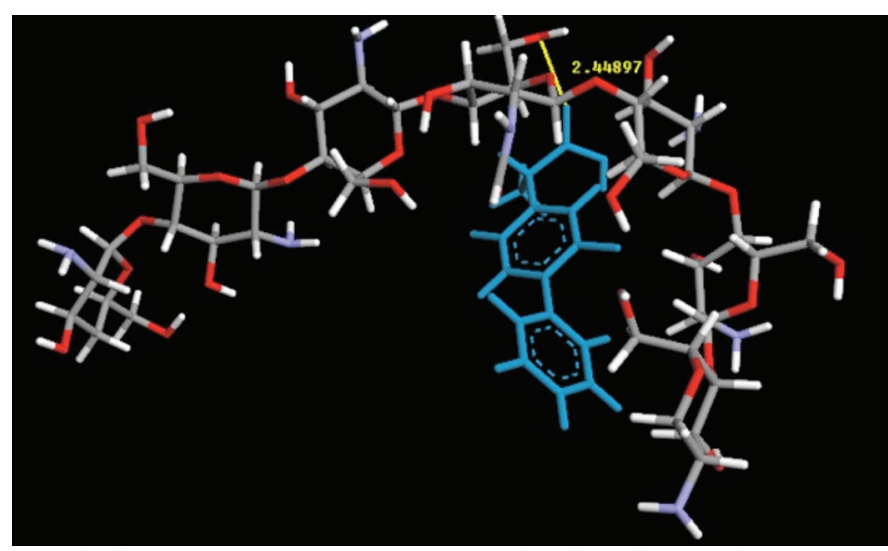

Figure 6. The best docked complexes structures of chitosan-flurbiprofen micro-nano spheres with $\Delta G$ binding energy $=-3.90 \mathrm{kcal} / \mathrm{mol}$

reason of the fast releasing of the first phase can be explained by adsorption of flurbiprofen on the spheres surface. In the second phase, flurbiprofen encapsulated in the chitosan was passed to the dispersion environment. Dudhani and Kosaraju ${ }^{27}$ revealed that the releasing behavior of micro or nanoparticles is generally biphasic. Biphasic patterns of drug-chitosan systems were reported by earlier studies.11,28,29 Biphasic releasing patterns were observed both in the present study and the study by Kawadkar and Chauhan ${ }^{14}$ but the releasing velocity of the present study was recorded about two times faster than that of the study by Kawadkar and Chauhan. ${ }^{14}$ While spray-drying method was used for producing the spheres, cross-linked agent was used in Kawadkar and Chauhan ${ }^{14}$ study. It can be concluded that this difference in the releasing velocity is because of the spheres producing methods. Consequently, our results proved that releasing behavior of flurbiprofen from CS-FP spheres produced by using spray-drying method was effective in order to improve controlled drug delivery system.

\section{Molecular docking}

The experimental results of encapsulation process of flurbiprofen were combined with the docking studies to investigate the possible binding sites of the chitosan. For this purpose, flurbiprofen was docked with the chitosan. The flexible docking results showed that flurbiprofen fitted into the active sites of the chitosan. The binding modes of the best docked CSFP complexes with the lowest energy are shown in the Figure 6. The binding energy of the docked structures of the CS-FP 
stable complexes was calculated as a value of $-3.90 \mathrm{kcal} / \mathrm{mol}$. As seen from the Figure 6 flurbiprofen was surrounded by the chitosan and bonded to chitosan through a new hydrogen bond between carboxyl oxygen of drug (0-174) and chitosan 0-35 atoms. The distance of $\mathrm{H}$ bond is evaluated as $2.449 \AA$. Our docking results supported to the spectroscopic results obtained by FTIR shown the H-bonding.

\section{CONCLUSION}

This study showed that it is also possible to produce CS-FP micro and nano spheres by using spray-drying method without any cross-linked agent. Structural details of the spheres were examined by using SEM, XRD and FTIR analysis. In vitro drug releasing and encapsulation efficiency were also studied. Our drug releasing results showed that release of encapsulated flurbiprofen was completed within 48h. Also it was determined that the releasing velocity of the spheres with spray-drying method was much faster than releasing velocity of spheres with genipin cross-linked. Here molecular docking explained the interaction between chitosan and flurbiprofen. The results of our docking studies can be useful for the design of new drug carrier systems with chitosan. The results of molecular docking can be suggested to use in further studies to explain of interactions between chitosan and the others drug active agents.

\section{ACKNOWLEDGEMENTS}

This study was supported by Aksaray University Scientific Research Projects Unit (Project Number: 2015-044).

\section{Conflict of Interest: No conflict of interest was declared by the} authors.

\section{REFERENCES}

1. Davies NM. Clinical pharmacokinetics of flurbiprofen and its enantiomers. Clin Pharmacokinet. 1995;28:100-114.

2. Naeem M, Rahman NU, Tavares G, Barbosa SF, Chacra NB, Loebenberg $\mathrm{R}$, Sarfraz MK. Physicochemical, in vitro and in vivo evaluation of flurbiprofen microemulsion. An Acad Bras Cienc. 2015;87:1823-1831.

3. Kumari A, Yadav SK, Yadav SC. Biodegradable polymeric nanoparticles based drug delivery systems. Colloids Surf B Biointerfaces. 2010;75:1-18.

4. Luo $Y$, Wang $Q$. Recent development of chitosan-based polyelectrolyte complexes with natural polysaccharides for drug delivery. Int J Biol Macromol. 2014;64:353-367.

5. Rinaudo M. Chitin and chitosan: Properties and applications. Prog Polym Sci. 2006;31:603-632.

6. Sanyakamdhorn S, Agudelo D, Tajmir-Riahi HA. Encapsulation of antitumor drug doxorubicin and its analogue by chitosan nanoparticles. Biomacromolecules. 2013;14:557-563.

7. O'Toole MG, Henderson RM, Soucy PA, Fasciotto BH, Hoblitzell PJ, Keynton RS, Ehringer WD, Gobin AS. Curcumin encapsulation in submicrometer spray-dried chitosan/tween 20 particles. Biomacromolecules. 2012;13:2309-2314.

8. Wu Y, Yang W, Wang C, Hu J, Fu S. Chitosan nanoparticles as a novel delivery system for ammonium glycyrrhizinate. Int $\mathrm{J}$ Pharm. 2005;295:235-245

9. Sarmento B, Ribeiro A, Veiga F, Sampaio P, Neufeld R, Ferreira D. Alginate/chitosan nanoparticles are effective for oral insulin delivery. Pharm Res. 2007;24:2198-2206.
10. De Campos AM, Sanchez A, Alonso MJ. Chitosan nanoparticles: a new vehicle for the improvement of the delivery of drugs to the ocular surface. Int J Pharm. 2001;224:159-168.

11. Hassani Najafabadi A, Abdouss M, Faghihi S. Synthesis and evaluation of PEG-O-chitosan nanoparticles for delivery of poor water soluble drugs: Ibuprofen. Mater Sci Eng C Mater Biol Appl. 2014;41:91-99.

12. Calija B, Cekic N, Savic S, Krajisnik D, Daniels R, Milic J. An investigation of formulation factors affecting feasibility of alginatechitosan microparticles for oral delivery of naproxen. Arch Pharm Res. 2011;34:919-929.

13. Del Gaudio P, Russo P, Lauro MR, Colombo P, Aquino RP. Encapsulation of ketoprofen and ketoprofen lysinate by prilling for controlled drug release. AAPS PharmSciTech. 2009;10:1178-1185.

14. Kawadkar J, Chauhan MK. Intra-articular delivery of genipin cross-linked chitosan microspheres of flurbiprofen: preparation, characterization, in vitro and in vivo studies. Eur J Pharm Biopharm. 2012;81:563-572.

15. Mokhtar M, Sammour OA, Hammad MA, Megrab NA. Effect of some formulation parameters on flurbiprofen encapsulation and release rates of niosomes prepared from proniosomes. Int J Pharm. 2008;361:104-111.

16. Ranjha NM, Khan H, Naseem S. Encapsulation and characterization of controlled release flurbiprofen loaded microspheres using beeswax as an encapsulating agent. J Mater Sci Mater Med. 2010;21:1621-1630.

17. Ranjha NM, Khan IU, Naseem S. Encapsulation and characterization of flurbiprofen loaded poly ( $\epsilon$-caprolactone)-poly (vinylpyrrolidone) blend micropheres by solvent evaporation method. J Sol-Gel Sci Techn. 2009;50:281-289.

18. Kang JH, Oh DH, Oh YK, Yong CS, Choi HG. Effects of solid carriers on the crystalline properties, dissolution and bioavailability of flurbiprofen in solid self-nanoemulsifying drug delivery system (solid SNEDDS). Eur J Pharm Biopharm. 2012;80:289-297.

19. Sosnik A, Seremeta KP. Advantages and challenges of the spray-drying technology for the production of pure drug particles and drug-loaded polymeric carriers. Adv Colloid Interface Sci. 2015;223:40-54.

20. Chen H, Lyne PD, Giordanetto F, Lovell T, Li J. On evaluating moleculardocking methods for pose prediction and enrichment factors. J Chem Inf Model. 2006;46:401-415.

21. Kim CK, Yoon YS, Kong JY. Preparation and evaluation of flurbiprofen dry elixir as a novel dosage form using a spray-drying technique. Int $J$ Pharm. 1995;120:21-31.

22. Mokhtar M, Sammour OA, Hammad MA, Megrab NA. Effect of some formulation parameters on flurbiprofen encapsulation and release rates of niosomes prepared from proniosomes. Int J Pharm. 2008;3610104-111.

23. Thompson MA, Planaria Software LLC, Seattle, WA, http://www.arguslab. com.

24. Skovstrup S, Hansen SG, Skrydstrup T, Schiott B. Conformational flexibility of chitosan: a molecular modeling study. Biomacromolecules. 2010;11:3196-3207.

25. Wavefunction, Inc. SPARTAN, v.06. Wavefunction, Inc., Irvine, 2006.

26. Luo $\mathrm{Y}$, Zhang $\mathrm{B}$, Cheng $\mathrm{WH}$, Wang $\mathrm{Q}$. Preparation, characterization and evaluation of selenite-loaded chitosan/TPP nanoparticles with or without zein coating. Carbohydr Polym. 2010;82:942-951.

27. Dudhani AR, Kosaraju SL. Bioadhesive chitosan nanoparticles: Preparation and characterization. Carbohydr Polym. 2010;81:243-251.

28. Joseph JJ, Sangeetha D, Gomathi T. Sunitinib loaded chitosan nanoparticles formulation and its evaluation. Int $\mathrm{J}$ Biol Macromol. 2016;82:952-958.

29. Arulmozhi V, Pandian K, Mirunalini S. Ellagic acid encapsulated chitosan nanoparticles for drug delivery system in human oral cancer cell line (KB). Colloids Surf B Biointerfaces. 2013;110:313-320. 